DOI 10.22460/infinity.v7i2.p133-146

\title{
GEOMETRY EXPLORATION ACTIVITIES ASSISTED WITH DYNAMIC GEOMETRY SOFTWARE (DGS) IN A TEACHER EDUCATION CLASSROOM
}

\author{
Samsul Maarif ${ }^{1}$, Wahyudin ${ }^{2}$, Muchamad Subali Noto ${ }^{3}$, Wahyu Hidayat ${ }^{4}$, \\ Herri Mulyono 5 \\ 1,5 Universitas Muhammadiyah Prof.Dr. HAMKA, Jl. Tanah Merdeka, Jakarta, Indonesia \\ ${ }^{2}$ Universitas Pendidikan Indonesia, JL. Setiabudi No. 229, Bandung, Indonesia \\ ${ }^{3}$ Universitas Swadaya Gunung Jati, JL. Pemuda No.32, Cirebon, Indonesia \\ ${ }^{4}$ IKIP Siliwangi, JL Terusan Jenderal Sudirman, Cimahi, Indonesia \\ ${ }^{1}$ samsul_maarif@uhamka.ac.id, ${ }^{2}$ wahyudin_math@yahoo.com, ${ }^{3}$ balimath61@gmail.com, \\ ${ }^{4}$ wahyu@ikipsiliwangi.ac.id, ${ }^{5}$ hmuyono@uhamka.ac.id
}

Received: August 07, 2018 ; Accepted: September 03, 2018

\begin{abstract}
The aims of this study were conducted to investigate the effectiveness of pre-service teachers' geometric exploration activities assisted by Dynamic Geometry Software (DGS) Cabri II Plus computer application in constructing geometry proofs in a teacher education classroom. To these ends, mix-method design. A total of 72 pre-service teachers taking geometry course participated in the study. Findings of the study show that students who participated in geometric exploration activities assisted by DGS Cabri II Plus computer application had better achievement compared to their counterpart. The use of DGS Cabri II Plus computer application was observed to enable the students to present diagrams of verification problems appropriately, determine the valid conjectures, and make justification regarding the statements in the written proof. More importantly, participating in geometric exploration activities assisted by DGS Cabri II Plus computer application provide students with opportunities to explore alternative proofs related to geometry.
\end{abstract}

Keywords: Dynamic Geometry Software, Cabri II Plus, Geometry.

Abstrak

Tujuan penelitian ini adalah mengetahui efektivitas ekplorasi geometri menggunakan Dynamic Geometry Software (DGS) Cabri II Plus dalam mengkonstruksi bukti geometri mahasiswa calon guru. Metode penelitian ini adalah metode kombinasi dengan jumlah sampel sebanyak 72 mahasiswa calon guru yang mengambil mata kuliah geometri. Temuan dalam penelitian ini menunjukkan bahwa siswa yang berpartisipasi dalam ekplorasi geometri menggunakan DGS Cabri II Plus lebih baik dibandingkan dengan rekan mereka. Penggunaan DGS Cabri II Plus memungkinkan siswa menyajikan diagram masalah verifikasi secara tepat, menentukan dugaan yang valid, dan membuat jastifikasi pernyataan pada bukti tertulis. Lebih penting lagi, siswa dapat berpartisipasi dalam kegiatan eksplorasi geometrik dengan menggunakan DGS Cabri II Plus yang memberikan peluang untuk mengeksplorasi bukti alternatif yang terkait dengan geometri.

Kata Kunci: Dynamic Geometry Software, Cabri II Plus, Geometri.

How to Cite: Maarif, S., Wahyudin, W., Noto, M. S., Hidayat, W., \& Mulyono, H. (2018). Geometry Exploration Activities assisted with Dynamic Geometry Software (DGS) in a Teacher Education Classroom. Infinity, 7(2), 133-146. doi:10.22460/infinity.v7i2.p133-146. 


\section{INTRODUCTION}

In the present study, the application of geometry exploration activities with Dynamic Geometry Software (DGS) Cabri Geomtery II Plus computer technology to construct a geometry proof during a geometry course in a teacher education classroom was investigated. Cabri Geometry II Plus (henceforth Cabri II Plus) is a computer application that helps students visualise abstract concepts on geometry, so students can easily understand and easier to arrange geometric proofs. (Maarif, 2017). The computer application enables students to construct dots, lines, triangles, circles and other plane geometries complete with calculations (Mariotti, 2002). Cabrilog as cited in Laborde (2002) suggests other benefits of Cabri Geometry II Plus, including simple and user friendly interface, understandable icons and fonts, support features for geometry learning, and export import facility.

The term geometry proof in this paper is operasionalised as a valid argument that establishes the truth of the statement (Jones \& Rodd, 2001). This argument is used to provide evidence or persuade other people to accept a belief (Bell, 1978) through sereies of explanations, findings, relation between mathematical ideas and the geometry problems (Marrades \& Gutiérrez, 2000) and systematic statements in an axiomatic system (Knuth, 2002). Bell (1978) suggests six alterantives that can help establish evidence or persuade people, inlcuding personal experience, acceptance of authority, observations of instances, lack of a counterexample, the usefulness of result, deductive argument. The later, the deductive argument is viewed as best alternative that can help to construct a geometry proof. It is because deductive reasoning employs the law of logic in relating the true statement to come to the right conclusion.

In mathematics classroom context, several studies have shown that students experienced difficulty in compiling geometry proofs. Students feel difficult to visualise the concept of geometry. Consequently, they cannot analyse, define conjecture, justify the problem and moreover to compiling geometric proofs (Knuth, 2002; Mariotti, 2002; Mariotti \& Balacheff, 2008). In preparing the proofs, students have trouble making intuition and only working on certain cases. As a result, the student can not determine the general form of proof, make a mistake in the proofs procedure and in selecting the technique, and the students also unable to apply counterexample in proofing. (Moore, 1994; Weber, 2005; Selden \& Selden, 2008; Arnawa, 2010; Perbowo \& Pradipta, 2017). To address this difficulties, DGS, particularly Cabri Geometry II Plus has been used in classroom instruction to explore geometric materials. The objective of exploration through such an applicaiton is to construct conjectures, justify and formulate ideas of proof (Jones, 2002, Rodríguez \& Gutiérrez, 2006; Mariotti, 2002; Oldknow, 2009; Baccaglini-Frank \& Mariotti, 2010; Kilic, 2013, Maarif, 2017). According to Sánchez \& Sacristán (2003), the use of tools such as DGS brings the possibility that students can understand the various geometry concepts that can help students in constructing a geometric proof. The activity of manipulating geometric shapes can help students to find and justify conjectures (Maarif, 2017).

This current study address two research questions as below:

1. Does the preservice teachers' application of geometry exploration activities with DGS Cabri II Plus computer application affect their ability in constructing geometry proof?

2. How do the preservice teachers perceive the application of geometry exploration activities assisted by DGS Cabri II Plus computer application? 


\section{METHOD}

A mixed-method design that combines two research strands i.e. quantitative and qualitative strand was adopted in this study (Creswell, et al., 2007). The quantitative research was carried out to examine the effect of the application of geometry exploration activities assisted with DGS Cabri II Plus in constructing a proof of geometry of pre-service teachers. In the quantitative stage, a quasi-experimental design was developed. A total of 72 preservice teachers attending Geometry course participated in this study and were grouped into an experimental and control groups. The experiment group received an intervention where DGS Cabri II computer application was incorporated during preservice teachers' geometric exploration activities in their attempts to construct geometry proofs. While in the control groups, the activity was conducted with a paper based-media.

Table 1. The difference of intervention procedure between two groups:

\section{Intervention in the Experimental group}

1. Teacher explained the students about geometry theorem

2. Teachers gave a geometry proof problem to the students

3. Students constructed geometry theorem on DGS Cabri II Plus worksheet

4. Students manipulated the figure they already constructed on the worksheet. The manipulation included labelling, determining the size of sides, angles and etc. using the software

5. Students highlight conjectures by labeling the causal effect between them on the worksheet for the proof construction

6. Students reconstructed geometry shapes they made in DGS Cabri II Plus, with information related to manipulation for constructing proof

7. Students developed the proof from conjectures they already determined

8. Students were encouraged to re-examine the geometry proof they already constructed

9. Teacher guided students' exploration activity to help them explore a proof

10. Students were given problems related to geometry proof

11. Students operated DGS Cabri II Plus to helped solve the problem they intended to prove

12. Students presented and explained the geometry proof

13. Teacher and students together concluded the lesson

\section{Intervention in the control group}

Teacher explained the students about geometry theorem

Teachers gave a geometry proof problem to the students

Students constructed geometry theorem manually on a piece of paper

Students manipulated the figure they already constructed on the worksheet. The manipulation included labelling, determining the size of sides, angles and etc. on the paper

Students highlight conjectures by labeling the causal effect between them on the worksheet for the proof construction

Students reconstructed geometry shapes they made on the paper, with information related to manipulation for constructing proof

Students developed the proof from conjectures they already determined

Students were encouraged to re-examine the geometry proof they already constructed

Teacher guided students' exploration activity to help them explore a proof

Students were given problems related to geometry proof

Students operated DGS Cabri II Plus to helped solve the problem they intended to prove

Students presented and explained the geometry proof

Teacher and students together concluded the lesson 
In addition, in the qualitative stage, preservice teachers' perception about of the exercise of geometric exploration activities assisted by Dynamic Geometry Software (DGS) Cabri II Plus computer application was explored.

\section{Data collection instruments and analysis}

The collection of the data in the current study were gathered using two methods. The quantitative data were collected through two set of tests: pre-test and post-test. These two tests were purposefully developed to evaluate students' ability in constructing a four item geometry proof, including conjecturing, formulating a statement, exploration, the selection and combination of coherent arguments, testing result, and writing a formal proof (Reis \& Reinkl, 2002). The pre-test was distributed to all participants from both experimental and control class before the Geometry course commenced and the post-test was given to the participants after eight weeks of application of geometry exploration activities assisted with DGS Cabri II Plus ended. The collected quantitative data were analysed statistically using SPSS software.

In addition to the quantitative data, the qualitative data were gathered through observation and interview. Two of seventy two preservice teachers' classroom activities from the experimental group were intensively observed and interviewed. Both observation as well as interview were video-recorded. Although the section of two out of seventy two preservice teachers rose concerns related to subjectivity as well as the validity of the finding from the qualitative data, the selection of small sample of two preservice teachers was purposefully to help the researchers focus and understand the detail of construction process of geometry proof with the use of DGS Cabri II Plus computer application. The recorded observation and interview first were transcribed verbatim. The qualitative data were then coded and analysed using a thematic analysis.

\section{RESULTS AND DISCUSSION}

\section{Research question one:}

Does the preservice teachers' application of geometric exploration activities with DGS Cabri II Plus computer application affect their ability in constructing geometry proof?

The first research question concerned whether the preservice teachers' application of geometric exploration activities with DGS Cabri II Plus computer application affect their ability in constructing geometry proof. To address the first research question, the research hypotheses were developed as below:

$H_{0}$ : There is no mean difference on the pre- and post-tests between the experimental and control group, $\mathrm{p}$-value $>\alpha$ with $\alpha$ is at 0.05

$H_{1}$ : There is a mean difference on the pre- and post-tests between the experimental and control group, $\mathrm{p}$-value $\leq \alpha$ with $\alpha$ is at 0.05

As mentioned earlier, the quantitative data were gathered using pre- and post-tests and the collected data were analysed statistically using t-test. Table 2 and Table 3 below present the statistical description of the data from the two groups and the t-test result respectively. 
Table 2. The description of data

\begin{tabular}{lccccc}
\hline & N & Minimum & Maximum & Mean & $\begin{array}{c}\text { Standard } \\
\text { Deviation }\end{array}$ \\
\hline Eexperimental group & 36 & 8.00 & 19.00 & 15.2778 & 3.36886 \\
Control group & 36 & 6.00 & 19.00 & 13.9167 & 2.94109 \\
Valid N (listwise) & 36 & & & & \\
\hline
\end{tabular}

Table 3. T-Test Results of Ability to Construct Geometry Proof of Experiment and Control Class

\begin{tabular}{ccccc}
\hline \multicolumn{2}{c}{ Construct the Geometry Proof } & $\boldsymbol{t}$ & $\boldsymbol{d} \boldsymbol{f}$ & $\begin{array}{c}\boldsymbol{p} \text {-value } \\
\text { (1-tailed) }\end{array}$ \\
\hline \multirow{2}{*}{ Posttest } & Equal variances assumed & 3.279 & 70 & 0.002 \\
& Equal variances not assumed & 3.279 & 68.768 & 0.002 \\
\hline
\end{tabular}

Table 3 as above shows that the calculation of t-test of preservice teachers' post-test resulted the $t$ value of 3.279 with the $p$-value of 0.002 . In reference to the research hypothesis, the $p$ value was observed to be lower than $\alpha=0.05(0.002<\alpha=0.05)$, allowing the rejection of $\mathrm{H}_{0}$. The rejection of $\mathrm{H}_{0}$ hypothesis indicated that there was a difference in preservice teachers' ability in geometry proof construction between the experimental and control groups. By observing the mean score as in the Table 2, it was shown that the preservice teachers in experimental group achieved better than those in the control group (Experimental group, mean score 15.278; the control group, mean score 13.917). In other words, the application of DGS Cabri II during geometric exploration activities helped teachers construct geometry proof better than those who did not use the application. To follow up the finding, the effect size test was calculated and the finding showed that the effect size was observed at .631 or at medium level.

The quantitative finding of the current study is in line with earlier study by Goldenberg (1995) and Laborde (2002). Goldenberg (1995) investigated the application of computer based mathematics learning at school suggested. The finding of his study suggested that the incorporation of computer technology in mathematics learning provided positive effect on students' criticality as well as creativity. Specifically, the finding showed that students' who used computer application in their mathematics learning achieved better in mathematics test compared to those who did not. Similarly, Laborde (2002) study examined the effect of Cabri Geometry use in mathematics classroom on students' mathematical representation ability. The result of her study showed that the Cabri II Plus use in junior secondary mathematics classroom affected positively on students geometric learning compared to the conventional method.

\section{Research question two:}

How do the preservice teachers perceive the application of geometric exploration activities assisted by DGS Cabri II Plus computer application?

The second research question explored teachers' perception about the application of geometric exploration activities assisted by DGS Cabri II Plus computer application. As 
discussed earlier in method section, two methods of data collection were employed to address the research questions namely observation and interview. Thematic analysis was carried out to perform the qualitative data analysis with the predetermined themes as in Table 4 below:

Table 4. Predetermined themes

\begin{tabular}{ccccc}
\hline \multirow{4}{*}{ Participant } & \multicolumn{4}{c}{ Themes } \\
\cline { 2 - 5 } & $\begin{array}{c}\text { Illustrating a } \\
\text { diagram of a } \\
\text { proofing problem } \\
\text { correctly (A1) }\end{array}$ & $\begin{array}{c}\text { Determining a } \\
\text { valid } \\
\text { conjecture } \\
\text { (A2) }\end{array}$ & $\begin{array}{c}\text { To justify the } \\
\text { statement in the } \\
\text { written proof }\end{array}$ & $\begin{array}{c}\text { Find new ideas of } \\
\text { proof, on } \\
\text { students. (A4) }\end{array}$ \\
\hline Dilla & 1 & 0 & 0 & 1 \\
Lia & 1 & 1 & 1 & 1 \\
\hline
\end{tabular}

Notes:

A1 : help students draw a diagram of the problem of proof correctly

A2 : help students determine valid conjectures

A3 : assist students in the contribution of justifying the statement in the written proof

A4 : helps students find new ideas of proofing on themselves.

0 : Response to failure

1 : Response to success

The names of Dilla and Lia are pseudonymous

The classroom narrative was employed to present the detail account of the application of geometry proof construction activity assisted by the DGS Cabri II Plus. The classroom instruction was below:

Prove that: If on $\triangle A B C$, the sides $A C$ and $B C$ each constructed equilateral triangle i.e. $\triangle A B D$ and $\triangle B C E$ outside $\triangle A B C$, then $A E=D C$.

The following subsections detail Dilla and Lia's exploration in their attempts to construct geometry proof.

\section{Detailed account of Dilla's exploration}

Dilla constructed an equilateral triangle $\mathrm{ABC}$. On the $\mathrm{AB}$ and $\mathrm{BC}$ sides, she create an equilateral triangle $\mathrm{ABD}$ and $\mathrm{CBE}$. Then, Dilla attempted to determine the length of the side of PE, AP, CQ and DQ by using existing services on Cabri II Plus. Figure 1 below draws Dilla's exploration using Cabri II Plus.
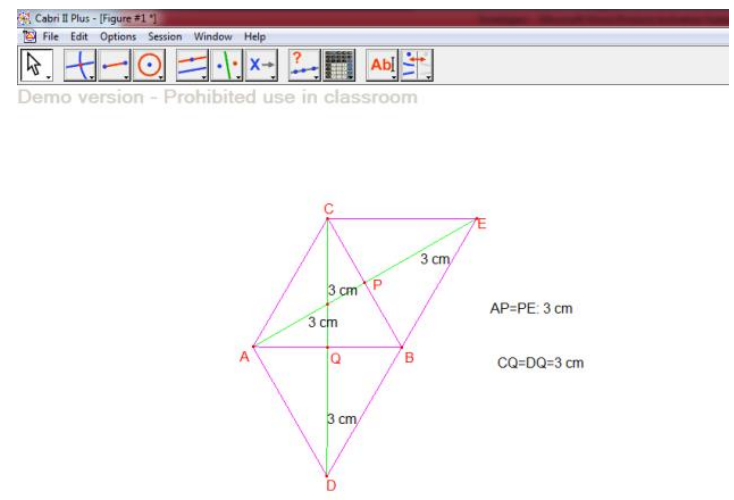

Figure 1. Results of Dilla Exploration Using Cabri II Plus 
As shown in the figure, the exploration shows that $A P=P E=C Q=D Q=3 \mathrm{~cm}$. This was reflected as Dilla thought $\mathrm{CQ}+\mathrm{QD}=\mathrm{PE}+\mathrm{AP}$ and this led her into a conclusion of $\mathrm{AE}=\mathrm{DC}$. Although Dilla misinterpreted the problem that the triangle $\mathrm{ABC}$ was known to be an arbitrary triangle not just an equilateral triangle, Dilla presented its conjecture by making an equilateral triangle. Throughout the exploration activities using Cabri II plus, Dilla invented an idea of new proofing on herself (See Table 4, A4 / 1), where the idea has never been thought of before. Figure 2 below details Dilla's construction process.

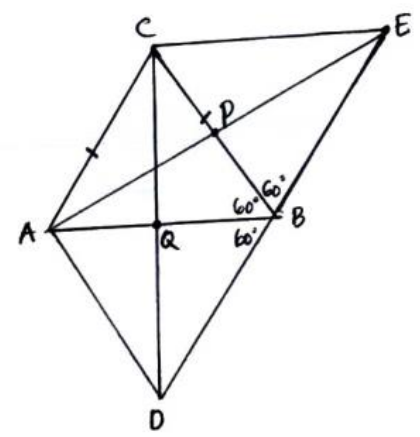

Diketahui :

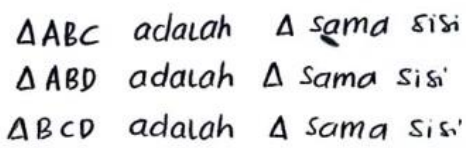

Akan dibuktikan : $A E=C D$

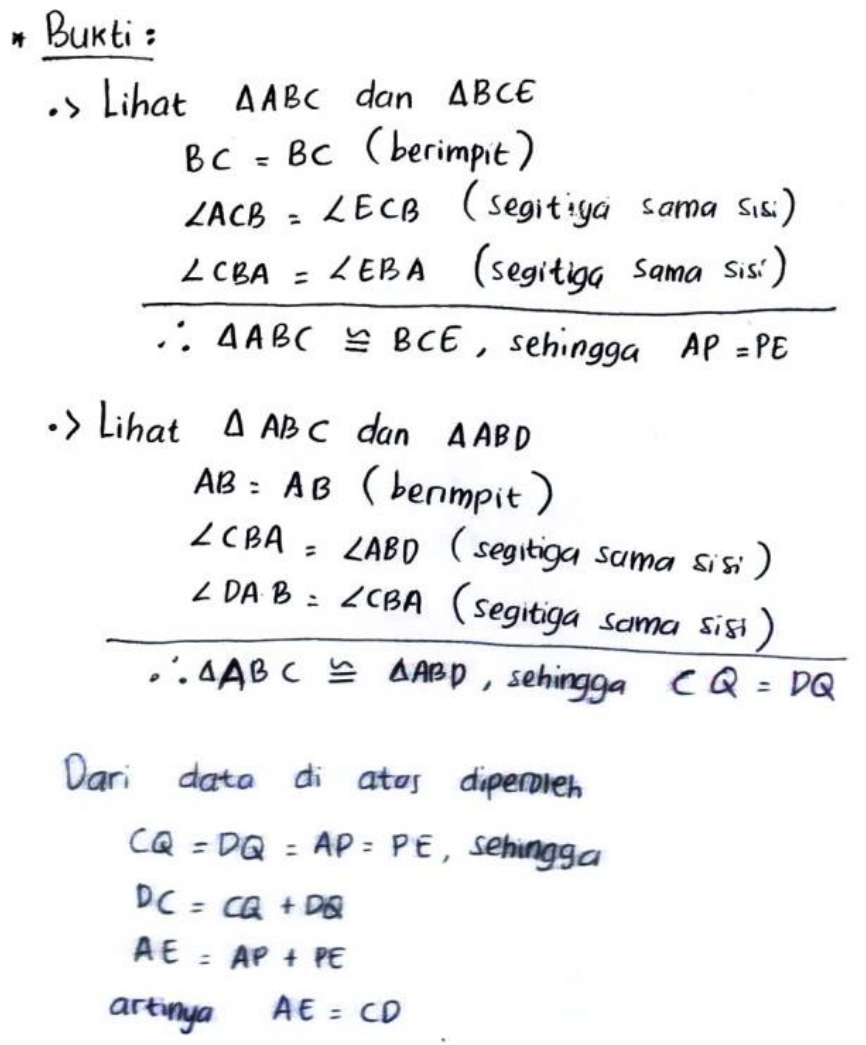

Figure 2. Dilla's Construction process

Translation of the Figure 2:

Interpretation of the problem:

$\triangle A B C$ is an equilateral triangle

$\triangle A B D$ is an equilateral triangle

$\triangle B C D$ is an equilateral triangle

Will be proven: $\mathrm{AE}=\mathrm{CD}$ 
Proof:

=) See $\triangle A B C$ and $\triangle B C E$

$\mathrm{BC}=\mathrm{BC} \quad$ (coincide)

$\angle A C B=\angle E C B \quad$ (an equilateral triangle)

$\angle C B A=\angle E B A \quad$ (an equilateral triangle)

$\therefore \triangle A B C \cong \triangle C B E$, thus $A P=P E$

=) See $\triangle A B C$ and $\triangle A B D$

$\begin{array}{ll}\mathrm{AB}=\mathrm{AB} & \text { (coincide) } \\ \angle C B A=\angle A B D & \text { (an equilateral triangle) } \\ \angle D A B=\angle C B A & \text { (an equilateral triangle) }\end{array}$

$\therefore \triangle A B C \cong \triangle A B D$, thus $C Q=D Q$

From the above data, we have,

$C Q=D Q=A P=P E$, thus

$D C=C Q+D Q$

$A E=A P+P E$

it means $A E=C D$

As in the figure 2 above, Dilla was shown to present that $\triangle A B C \cong \triangle B C E$, suggesting $B C=B C$ (coincide), $\angle A C B=\angle E C B$ (an equilateral triangle) and $\angle C B A=\angle E B A$ (an equilateral triangle), and thus $\mathrm{AP}=\mathrm{PE}$. Further, Dilla assumed that $\triangle A B C \cong \triangle A B D$ because $A B=A B$ (coincide), $\angle C B A=\angle A B D$ (an equilateral triangle) and $\angle D A B=\angle C B A$ (an equilateral triangle), and thus $C Q=D Q$. With these two arguments, she concluded that $C Q=D Q=A P=P E$, $C D=C Q+D Q$ and $A E=A P+P E$, consequently $C Q=D Q$.

From Dilla's answer, it was observed some inaccuracies in her writing of proof argument. The interview script below highlights Dilla's argument for doing so.

Interviewer : The answer you have given is very impressive to me, so it is interesting to dig deeper. In the answer, you write that $\triangle A B C \cong \triangle B C E$ causes $A P=P E$ and $\triangle A B C \cong \triangle A B D$ results in $C Q$ $=Q D$. What is your explanation?

Dilla : Here is my explanation, $A P$ is a high line of $A B C$ triangle and $P E$ is a high line of $B C E$ triangle. Because $\triangle A B C \cong \triangle B C E$ then $A P=P E$ (coded A3/0).

Interviewer : So do you think if the two triangles are mutually congruent, then the height of the two triangles is the same?

Dilla : Yes sir, always the same.

Interviewer : Could you explain it in more detail?

Dilla : While exploring with Cabri II plus, I measured the triangle's high line. Then I noticed that all three triangles have the same height. Thus, since all three are equilateral triangles, they are the same height (coded A2 / 1).

From the interview above, it was shown that Dilla apparently employed a different perspective about the concept of the two triangular congruences. Typically, when it comes to 
the concept of congruence of two triangles, Dilla should have connected to the corresponding sides length, and the corresponding angles which allowed her to obtain the fact that the sides were actually at the same length, and the angle was the same. However, Dilla argued that if two triangles were congruent, then the height of the one corresponding side would also be equals. Her argument indicated that exploration with Cabri II helped Dilla constructed a novelty answer. Geometry exploration activities with Cabri II plus thus may shape the novelty of individual thinking which thus promote the development of a geometric proof ability.

With regards to determination of the conjecture, Dilla misconstrued the proof from which she was observed to pay a little attention to the notation on the construction of the image. As suggested in the DGS Cabri II plus manual, users are required to focus on the correct geometric image notations. In the Cabri II plus application, users could use angle and label to determine geometric image notations. Despite of misconstruction Dilla had made, Dilla exploration activities in Cabri II plus had helped Dilla in creating a diagram of the verification problem correctly (see Table 4, A1/1 and figure 2).

Interviewer : I am impressed with the idea you had described. However, I observe a less complete use of the notation in your answer. For example, you assume $P E$ is a high line on the ABE triangle, but the notation $P E \perp A B$ does not exist. What is your opinion?

Dilla : Oh, .. yes sir! I forgot the notation should be written to help me. Probably because there is no sign in the software, but there is a "mark angle" pack, I forgot to make it (Coded A1/1).

Interviewer : In your opinion, to what extent does the notation function in geometry drawings help you construct geometric proofs?

Dilla : Very helpful sir. When we describe the geometric shape of the problem of proof, the drawing must be precise complete with the notation. Usually, it makes me confused when the notation false.

Interviewer : What kind of confusion?

Dilla : For example like I cannot make conjectures, and usually, later the theorem used is wrong.

In addition, during her exploration activity, Dilla was observed to take one case of an equilateral triangle. While, the problem of proof is fundamentally an arbitrary triangle which also included types other than an equilateral triangle. The positive aspect from Dilla's exploration however, Dilla was able to use her knowledge to determine a new conjecture in relation with the concept of two triangular congruences.

\section{Detailed account of Lia's exploration}

During an observation on Lia's exploration activity, it was observed that Lia had made several attempts to explore the problem by creating any arbitrary triangle $\mathrm{ABC}$. Lia then adjusted the triangle into an equilateral triangle, each was on $\mathrm{AB}$ and $\mathrm{BC}$ side. Lia put forward a conjecture put to indicate two congruent triangles. Different colours were applied to highlight a mutually congruent.

In the next step, Lia was observed to determine the length of the $A B=B D=6 \mathrm{~cm}, B C=B E=7$ $\mathrm{cm}$ and $m \angle A B E=m \angle C B D=103^{\circ}$. Such a length determination enabled Lia to make a conclusion that $\triangle A B E \cong \triangle C B D$ that led $\mathrm{AE}=\mathrm{BE}$. To this stage, Lia was shown to have an ability to illustrate the problem in reference to the image that she had constructed using Cabri II plus. Throughout the exploration activities, Lia was enabled to explore ideas herself in 
order to help her solve the problem of proof. Lia's result of exploration is drawn in Figure 3 below.
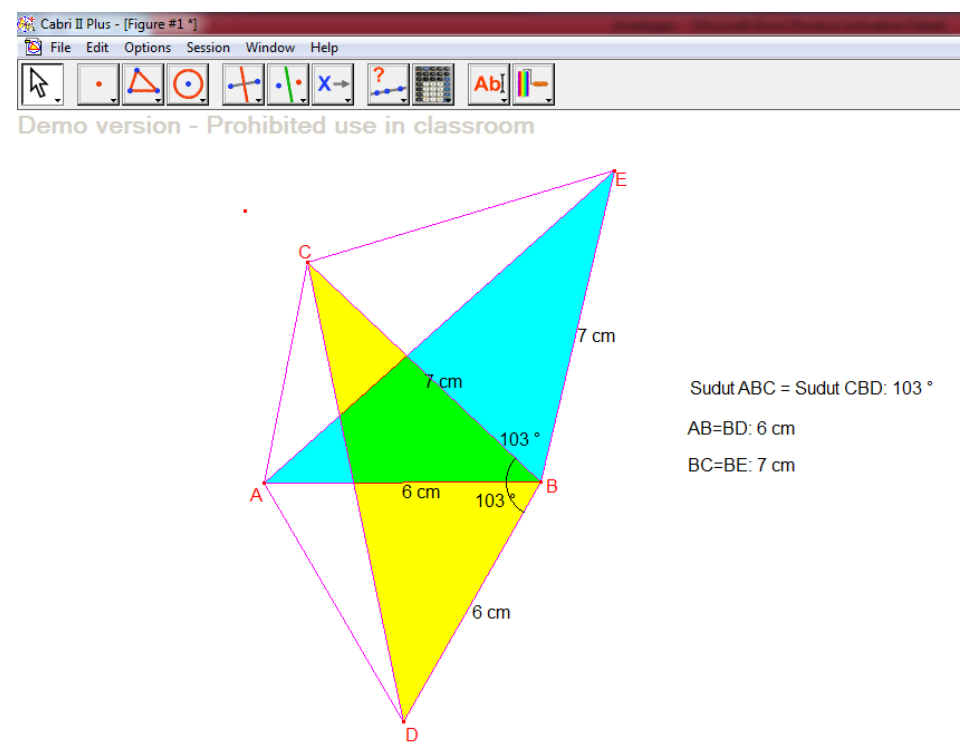

Figure 3. Results of Lia's Exploration Using Cabri II Plus

To better understand about Lia's exploration, we conducted an interview. Here are the results of the interview.

Interviewer : Could you please explain your answer?

Lia $\quad$ : Yes sir, when I did the exploration with Cabri II Plus, I suspected that $\triangle A B E \cong \triangle C B D$ That's why I put the colour, the first was yellow, and the other was blue (Coded A1 /1).

Interviewer : What is your purpose of giving a different colour to the two triangles?

Lia : To make it easier for me to highlight both triangles (Coded Al/1).

Interviewer : What does it mean to see both triangles? What do you want to see?

Lia : Yes sir, I mean to make it easier to determine which side is the same and which angle is the same. So I specified the side size that I need as well as the angle with the "distance or length" and "angle" buttons.

Interviewer : I am very impressed with your exploration, Does your exploration help you in determining the conjecture for proof?

Lia : I found that there were two equal sides and one same angle, $A B=$ $B D=6 \mathrm{~cm}, B C=B E=7 \mathrm{~cm}$ and $m \angle A B E=m \angle C B D=103^{\circ}$. So that the two triangles were congruent because it met the requirements of Side, Angle, Side. (Code A2 /1)

From the above interview, students' exploration with Cabri II plus was shown to enable them to obtain conjectural solutions for a proof. Applying colours to the two triangles that they considered congruent, was a creative step during the exploration stage. Moreover, the exploration tools in Cabri II plus seemed to have helped the students in determining the length of the sides or the degree of the angles in order to justify the validity of the argument (Coded 
A2/1) and the statement in the proof (Coded A3/1). After the exploration, Lia wrote down the proof to explain her exploration activities and it is presented in the following figure 4.

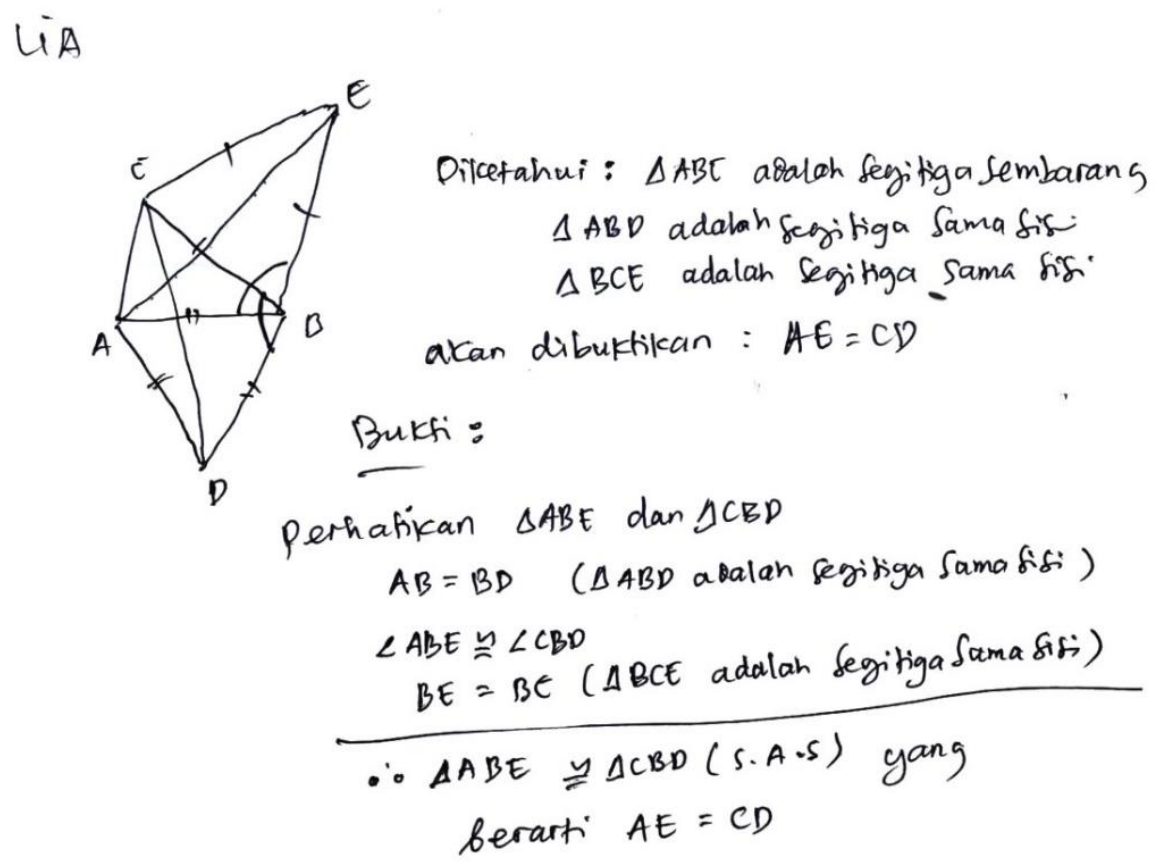

Figure 4. Lia's Construction process

Translation of Figure 4.

Interpretation of the problem:

$\triangle A B C$ is an arbitrary triangle

$\triangle A B D$ is an equilateral triangle

$\triangle B C D$ is an equilateral triangle

Will be proven: $\mathrm{AE}=\mathrm{CD}$

Proof:

See $\triangle A B E$ and $\triangle C B D$

$A B=B D \quad(\triangle A B D$ is an equilateral triangle $)$

$\angle A B E \cong \angle C B D$

$B E=B C \quad(\triangle B C E$ is an equilateral triangle $)$

$\therefore \triangle A B E \cong \triangle C B D(S . A . S)$, so that $A E=C D$

As in the figure 4 above, Lia's proof was observed as simpler but easy to accept compared to Dilla's. From her work of Cabri II plus, Lia seemed to have already understands comprehended the concept of conjecture of two congruent triangles which helped her determine the triangles. Lia was observed to construct the proof by conjecturing $A B=B D$ shwoing that triangle $A B D$ was an equilateral triangle. It was therefore, as observed in Lia's work, $\angle A B E \cong \angle C B D$ and $\mathrm{BE}=\mathrm{BC}$, suggesting that $\mathrm{BCE}$ was an equilateral triangle. Accordingly, $\triangle A B E \cong \triangle C B D$ (S.A.S) which shows that $A E=C D$. The concept of Lia's proof is shown in an interview with her as below. 


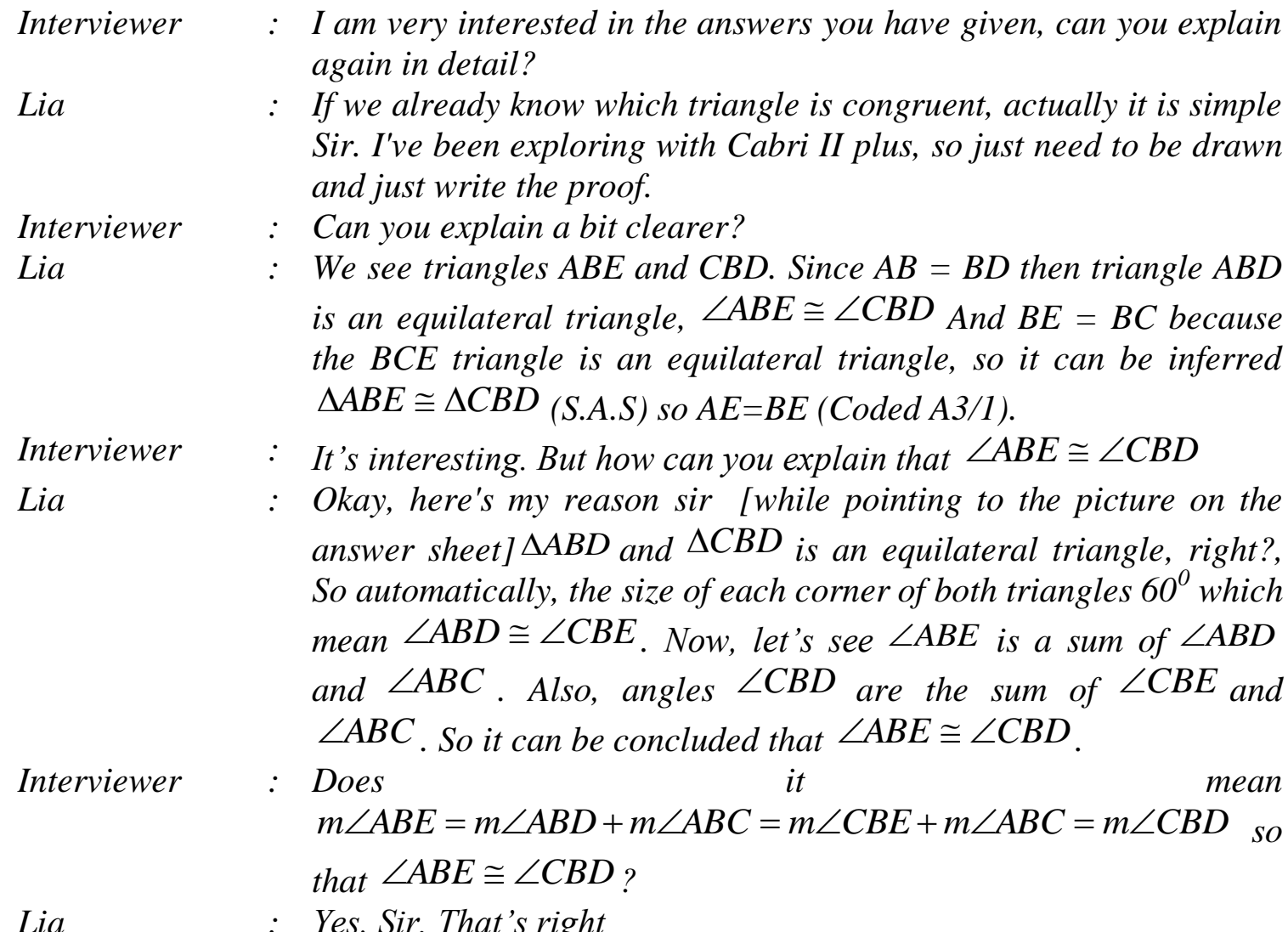

The qualitative finding as revealed in the current study suggest benefits from incorporating DGS Cabri II Plus in students' geometry learning. The use of such a computer application helped students in creating and presenting the geometry proof construction. This finding corresponds Mariotti \& Balacheff (2008) thought the existence of visual tools may help students to understand and construct the logic of proofing. It is because, as Marrades \& Gutiérrez (2000) views, geometry proof functions to explain, discover, as well as communicate mathematical alternatives to address issues in geometry. To this view, visual tool helps students to develop a theorem that they will use to construct a proof. The qualitative finding of the current study has shown that with the use DGS Cabri II Plus, students were given opportunities to create and manipulate figures which allowed them to point out valid conjectures. More importantly, from students' exploration activity it was shown that Cabri II Plus enabled them to construct a valid argument by dragging the figure construction they had already created, adding guidelines and setting up the lengths and angles (Maarif, 2017). The finding is also in line with what several authors (e.g. Jones, 2002, Rodríguez \& Gutiérrez, 2006; Mariotti, 2002; Baccaglini-Frank \& Mariotti, 2010; Kilic, 2013; Maarif, 2017) have suggested that the use of DGS in geometry learning facilitate geometry exploration activity, particularly in reference to determining conjecture as well as developing alternative to construct a geometry proof.

\section{CONCLUSION}

This current research addressed two research questions. First the research question concerns with whether the preservice teachers' application of geometric exploration activities with DGS Cabri II Plus computer application affect their ability in constructing geometry proof. Findings from the experimental research in the study showed that there were mean difference 
in geometry tests between students who used DGS Cabri II Plus in constructing geometry proof and those who did not. In other words, students' use of DGS Cabri II Plus in constructing geometry proof helped improve their attainment in geometry test. The effect size of such use of DGS Cabri II Plus was at a medium level.

Second research question asks how the preservice teachers perceive the application of geometric exploration activities assisted by DGS Cabri II Plus computer application. Findings from observation and interview showed that students' exploration activities in DGS Cabri II Plus benefited students in constructing geometry proof. In particular, it helped students to create correct diagram of the problem, determine a valid conjecture, justify the statement in a written proof, and facilitate the students in exploring alternative ways to construct geometry proof.

\section{REFERENCES}

Arnawa, I. (2010). Mengembangkan Kemampuan Mahasiswa dalam Memvalidasi Bukti pada Aljabar Abstrak melalui Pembelajaran Berdasarkan Teori APOS. Jurnal Matematika \& Sains, 14(2), 62-68.

Baccaglini-Frank, A., \& Mariotti, M. A. (2010). Generating conjectures in dynamic geometry: The maintaining dragging model. International Journal of Computers for Mathematical Learning, 15(3), 225-253.

Bell, F. H. (1978). Can computers really improve school mathematics?. The mathematics teacher, 71(5), 428-433.

Creswell, J. W., Hanson, W. E., Clark Plano, V. L., \& Morales, A. (2007). Qualitative research designs: Selection and implementation. The counseling psychologist, 35(2), 236-264.

Goldenberg, E. P. (1995). Multiple representations: A vehicle for understanding understanding. Software goes to school: Teaching for understanding with new technologies, 155-171.

Jones, K. (2002). Research on the use of dynamic geometry software: Implications for the classroom. MicroMath, 18(3), 18-20.

Jones, K., \& Rodd, M. (2001). Geometry and proof. Proceedings of the British Society for Research into Learning Mathematics, 21(1), 95-100.

Kilic, H. (2013). The effects of dynamic geometry software on learning geometry. In Proceedings from CERME 8: The 8th European Society for Research in Mathematics Education Conference.

Knuth, E. J. (2002). Teachers' conceptions of proof in the context of secondary school mathematics. Journal of Mathematics Teacher Education, 5(1), 61-88.

Laborde, C. (2002). Integration of technology in the design of geometry tasks with CabriGeometry. International Journal of Computers for Mathematical Learning, 6(3), 283317.

Maarif, S. (2017). Mengkonstruksi Bukti Geometri melalui Kegiatan Eksplorasi Berbantu Cabri II Plus. Euclid, 3(2). 
Marrades, R., \& Gutiérrez, Á. (2000). Proofs produced by secondary school students learning geometry in a dynamic computer environment. Educational studies in mathematics, 44(1-2), 87-125.

Mariotti, M. A. (2002). Justifying and proving in the Cabri environment. International Journal of Computers for Mathematical Learning, 6(3), 257-281.

Mariotti, M. A., \& Balacheff, N. (2008). Introduction to the special issue on didactical and epistemological perspectives on mathematical proof. ZDM: The International Journal on Mathematics Education, 40(3), 341-344.

Moore, R. C. (1994). Making the transition to formal proof. Educational Studies in mathematics, 27(3), 249-266.

Oldknow, A. (2009). ICT bringing mathematics to life and life to mathematics. The Electronic Journal of Mathematics and Technology, 3(2), 137-148.

Perbowo, K. S., \& Pradipta, T. R. (2017). Pemetaan Kemampuan Pembuktian Matematis sebagai Prasyarat Mata Kuliah Analisis Real Mahasiswa Pendidikan Matematika. KALAMATIKA Jurnal Pendidikan Matematika, 2(1), 81-90.

Rodríguez, F., \& Gutiérrez, A. (2006). Analysis of proofs produced by university mathematics students, and the influence of using Cabri software. In Proceedings of the 30th PME International Conference , 4, 433.

Sánchez, E., \& Sacristán, A. I. (2003). Influential Aspects of Dynamic Geometry Activities in the Construction of Proofs. International Group for the Psychology of Mathematics Education, 4, 111-118.

Selden, A., \& Selden, J. (2008). Overcoming students' difficulties in learning to understand and construct proofs. Making the connection: Research and teaching in undergraduate mathematics, 95-110.

Weber, K. (2005). Problem-solving, proving, and learning: The relationship between problem-solving processes and learning opportunities in the activity of proof construction. The Journal of Mathematical Behavior, 24(3-4), 351-360. 